\title{
The Effect of 6 Week Nordic Hamstring Exercise on Sprint and Jumping Performance*
}

\author{
Mehmet GÜL ̈̈1 1 , Ali Ahmet DOĞAN 1 \\ ${ }^{1}$ Kurıkkale University, Faculty of Sport Sciences, KIRIKKALE.
}

Original Article

Received: 04.08.2021
Accepted: 09.12.2021

DOI:10.25307/jssr.978869

Online Publishing: 31.12.2021

\begin{abstract}
The purpose of this study was to examine the effect of 6-week eccentric hamstring strength training on vertical jump and sprint performance. There were 19 male active participants in the study, of which 10 were in the experimental group and 9 in the control group. Pre-test and post-test measurements of the participants in the study were taken. Participants' 5-m, 10-m and 30meter sprint, vertical jump were measured. The SPSS 17.0 package program was used in the analysis of the data, and the test values of the participants were analyzed with the Wilcoxon Signed Ranks test. According to the findings obtained from the research results, in the statistical comparison of the 5-m, 10-m and 30-meter sprint test results of the experimental group participants before and after the training, there was no significant difference between the 5-m sprint pre-test and post-test values of the participants in the research ( $p>0.05$ ), there was a significant difference between the $10 \mathrm{~m}$ and $30 \mathrm{~m}$ sprint test pretest and post-test values $(\mathrm{p}<0.05)$. As a result, Nordic hamstring training small to moderately improved both sprint and vertical jump performance.
\end{abstract}

Keywords: Eccentric training, vertical jump, sprint, hamstring muscle.

\section{Haftalık Nordik Hamstring Egzersizinin Sprint ve Sıçrama Performansına Etkisi}

$\ddot{\mathbf{O} z}$

Bu çalışmanın amacı, 6 haftalık eksantrik hamstring kuvvet egzersizinin dikey sıçrama ve sprint performansı üzerindeki etkisini incelemektir. Araştırmada deney grubunda 10, kontrol grubunda 9 olmak üzere toplam 19 erkek aktif katılımcı yer almıştır. Araştırmaya katılanların ön test ve son test ölçümleri alınmıştır. Katılımcıların $5 \mathrm{~m}, 10 \mathrm{~m}$ ve $30 \mathrm{~m}$ sprint, dikey sıçrama performansları ölçülmüștür. Verilerin analizinde SPSS 17.0 paket programı kullanılmıș ve veriler Wilcoxon Signed Ranks testi ile analiz edilmiştir. Araştırma sonuçlarından elde edilen bulgulara göre, deney grubunda yer alan katılımcıların antrenman öncesi ve sonras $15 \mathrm{~m}, 10 \mathrm{~m}$ ve $30 \mathrm{~m}$ sürat testi sonuçlarının istatistiksel olarak karşılaştırıldığında $5 \mathrm{~m}$. sprint ön test son test arasında anlamlı farklılık bulunmamıştır ( $>>0.05$ ), $10 \mathrm{~m}$ ve $30 \mathrm{~m}$ sprint testi ön test ve son test değerleri arasında anlamlı fark bulunmuştur $(\mathrm{p}<0.05)$. Sonuç olarak, Nordik hamstring egzersizi hem sprint hem de dikey sıçrama performansını küçük ila orta derecede artırmıştır.

Anahtar kelimeler: Eksantrik antrenman, dikey sıçrama, sprint, hamstring kası.

* This study was produced from Mehmet GÜLÜ's master thesis.

†Corresponding Author: Mehmet GÜLÜ, Dr., e-mail: mehmetgulu80@gmail.com 


\section{INTRODUCTION}

Strength is a physiological concept used to refer to one of the output capabilities of the motor system (Enoka, 1988). Lower body strength, on the other hand, plays an important role in the performance of a soccer player on the field, as in many athletes (Turner, Munro \& Comfort, 2013). Many studies have found that lower body strength is associated with sprint performance and change of direction (McFarland, Dawes, Elder, \& Lockie, 2016; Nimphius, McGuigan, \& Newton, 2010). For this reason, improving strength is a top priority for many athletic performance trainers (Dawes \& Lentz, 2012). According to Dawes \& Lentz, (2012) there are several ways to improve power to improve speed. Thus, the relative and absolute strength can be increased by the combination of weightlifting and plyometric resistance training applied to the lower body (Dawes \& Lentz, 2012).

Jumping, which is an important parameter in winning or changing the score in the pitch, is a movement that requires motor coordination between the upper and lower parts of the body. Dowling \& Vamos, (1993) concluded that jump height is highly correlated with maximum power. Development of methods to increase the jump height will also provide significant improvements in the success graph of the athlete. In addition, it has great importance in many sports branches such as short-distance sprints (football, basketball, rugby) in the field. Especially in football, which is the most popular sport (Aydın, Sunay, Bal, \& Ayyıldız, 2019) today, it requires high intensity maximal repetitive movements as well as technical, tactical and physical skills (Shalfawi, Haugen, Jakobsen, Enoksen, \& Tønnessen, 2013; Stølen, Chamari, Castagna, \& Wisløff, 2005). In a standard soccer match, athletes frequently perform sprints of less than 6 seconds on average in each 90 -second period of the game, high-intensity changes of direction between 1200-1400, and compete at 80-90\% of their maximum heart rate (Shalfawi et al., 2013; Stølen et al., 2005). Considering these changes in the game structure, sprint has great importance in game dynamics.

Many explosive game dynamics, such as sprinting and vertical jumping, are an important component in many sports. It is especially critical for sports involving throwing, jumping, and short distance sprints that require explosive properties. Many studies have been conducted to develop and evaluate strength and power (Aras et al., 2020; Güçlüöver \& Gülü, 2020). It is of great importance to determine the dominant/nondominant, agonist/antagonist strength differences and to plan exercises in this direction. The hamstring muscle is important in both preventing injuries and increasing performance (Al Attar, Soomro, Sinclair, Pappas, \& Sanders, 2017; Ishøi et al., 2018). Hamstring injuries are one of the most common injuries in almost all team and individual sports involving the lower body (Bennell \& Crossley, 1996; Moseley, 1996; Orchard, James, Alcott, Carter, \& Farhart, 2002; Orchard, Wood, Seward, \& Broad, 1998). Hamstring injuries, one of the most common sports injuries in the lower extremity, account for more than $12 \%$ of all sports injuries (Alonso et al., 2012; Brooks, Fuller, Kemp, \& Reddin, 2005; Ekstrand, Hägglund, \& Waldén, 2011; Elliott, Zarins, Powell, \& Kenyon, 2011; Feeley et al., 2008; Orchard, Seward, \& Orchard, 2013). The fact that only a single muscle region is more than $12 \%$ in the total injury rate has increased the number of studies. Hamstring muscles are often neglected muscle groups in training. 
Hamstring strength has been shown to play a major role in increasing or decreasing the risk of hamstring strain injury (Bourne, Opar, Williams, \& Shield, 2015; Opar et al., 2015; Timmins et al., 2016). Various contraction methods are necessary to increase hamstring strength. The most important of these, eccentric contractions occur in daily motor activities and are generally responsible for two important features of movement. Eccentric contractions allow mechanical energy to dissipate during body deceleration (Konow \& Roberts, 2015). Eccentric contructions also allow the conversion of kinetic energy into elastic energy of tendons (Hoppeler, 2014). Eccentric movements during maximal voluntary isokinetic exercise generally result in lower muscle activity than concentric movements (Franchi, Reeves, \& Narici, 2017), but the maximum strength are significantly higher (Fang, Siemionow, Sahgal, Xiong, \& Yue, 2001).

Nordic hamstring exercise (NHE) is a hamstring training method known to increase eccentric strength, which can be performed in the field as well and can be performed without the need for any extra equipment (Mjølsnes, Arnason, Østhagen, Raastad, \& Bahr, 2004). The NHE is understood to be an eccentric exercise that is performed on the knees with ankles held/strapped with subjects lowering their upper body towards a prone position, as slowly as possible. This training method has been shown to increase eccentric hamstring strength more effectively than traditional hamstring exercises (Mjølsnes et al., 2004). However, the effects of this training method on dynamic performance are unknown. Studies on the effect of hamstring muscle on performance are limited in the literature. We hypothesis that eccentric hamstring exercise has positive effect on explosive power. In this contex the purpose of this study was to examine the effect of 6-week eccentric hamstring strength training on vertical jump and sprint performance.

\section{METHOD}

\section{Participant and Study Design}

This research consists of physically active participants. The number of participants was determined by the $\mathrm{G}^{*}$ power analysis method (Faul, Erdfelder, Lang, \& Buchner, 2007). The study consisted of 19 male participants, 10 of which were in the experimental group and 9 in the control group. One participant left the study voluntarily. Participants were divided into 2 groups as experimental and control 5-m, 10-m and 30-meter speed and vertical jump tests were performed before and after 6 weeks in this study. The participants in the study did not do any strength training other than the training program applied for the lower extremities during the study. One week before the start of the research, the participants were taken to the laboratory and gym where the study would take place, and detailed information was given to all participants about the tests to be performed. The participants were asked not to do any physical activity at least 24 hours before the measurement day, and the participants were asked to be ready at the gym where the measurements would be made at least 1 hour before the measurement day. In order to standardize the measurements, pre-test and post-test measurements were made by the same measurement team. The participants did not do any warm-up while taking the height and body weight measurements (the participants did the warm-up exercises before the vertical jump and sprint performance measurements after the height and body weight measurements were completed). Before the vertical jump test, the participants warmed up for 5 minutes and stretched for the lower extremities, then the 
participants performed 2 jumps with their hands on the waist in the passive squat position on the jump mat, and their best values were recorded. They rested for 5 minutes between the two jump tests. After the vertical jump test, the participants rested for at least 5 minutes, then 5-m, 10-m and 30-meter sprint values were taken with photocell and performed 2 repetitions. Participants rested for 5 minutes between two repetitions and their best values were recorded.

Table 1. Demographic characteristics of the research group

\begin{tabular}{lcccccc}
\hline & \multicolumn{3}{c}{ Experimental Group } & \multicolumn{3}{c}{ Control Group } \\
\hline Age (year) & $\mathbf{n}$ & $\mathbf{x}$ & $\mathbf{s s}$ & $\mathbf{n}$ & $\mathbf{x}$ & ss \\
Height $(\mathrm{Cm})$ & 10 & 21,10 & 1,85 & 9 & 21,67 & 3,50 \\
Weight $(\mathrm{Kg})$ & 10 & 1,75 & 0,03 & 9 & 1,79 & 0,06 \\
BFP (\%) & 10 & 69,53 & 5,71 & 9 & 71,43 & 10,00 \\
BMI & 10 & 22,45 & 4,15 & 9 & 11,99 & 2,48 \\
& 22,56 & 2,01 & 9 & 22,12 & 2,61 \\
\hline
\end{tabular}

BFP, Body Fat Percantege; BMI, Body Mass Indeks

\section{Nordic Hamstring Exercise Protocol}

In this exercise, the participant is in the starting position above the knee, while he is on the knee, he keeps his trunk tensely upright, and the training partner applies pressure to the ankles of the participant, ensuring that the feet do not lose contact with the ground during the execution of the movement and the hamstring muscle is contracted. At the beginning of the exercise, the participant keeps the training partner's ankle in a way that fixes it, then slowly lowers his body to the ground without disturbing it vertically, and while doing so, he tries to lower his body slowly by applying resistance to gravity as much as possible. During the descent of the trunk towards the ground, the participant protects himself by touching the ground with his hand close to the ground in order to prevent possible injuries, this exercise is repeated according to the number of repetitions in the planned program (Mjølsnes et al., 2004).

Table 2. Nordic hamstring exercise program

\begin{tabular}{ccc}
\hline Week & Training session/week & Repetitions and Sets \\
\hline 1 & 1 & $2 \times 5$ \\
2 & 2 & $2 \times 6$ \\
3 & 3 & $2 \times 6-8$ \\
4 & 3 & $2 \times 8-10$ \\
5 & 3 & $3 \times 12-10-8$ \\
6 & 3 & $3 \times 12-10-8$ \\
\hline
\end{tabular}

Adapted from Oslo Sports Trauma Research Center (2004) (Mjølsnes et al., 2004)

\section{Anthropometric Measurements}

The height of the participants in this study; Anatomical posture, bare feet, feet together, holding breath, head in the frontal plane, after positioning the overhead plate touching the vertex point, was measured with a (Seca) height meter with an accuracy of $0.1 \mathrm{~cm}$. The body weights of the participants were measured with a (tanita) with a sensitivity of $0.1 \mathrm{~kg}$, only in shorts, in bare feet and in anatomical posture. 


\section{Vertical Jump}

Before the vertical jump test, all participants warmed up for 5 minutes. Then, after stretching for the lower extremities, they wait on the jump mat in a passive squat position at 90 degrees, and when they were ready, they jump to the maximum height they can jump and the jump value was recorded. Participants rested for 5 minutes between 2 tests and performed the second repetition and their best values were recorded.

\section{Sprint}

Sprint tests before the 5-m, 10-m and 30-m sprint test applied to the research group, each participant did a 10-minute free warm-up and stretching exercise. In order to eliminate the ground effect in the sprint tests, all the sprint tests in the study were done in the gym. The 5-m, 10-m and 30-meter distance was measured with a tape measure, and double-eyed photocell doors were placed at the end of the initial 5-m, 10-m and 30-m. In the measurements, the participants will stand one meter behind the starting photocell door and start running as soon as they were ready. The time will start automatically when the participants pass through the starting photocell door, stop automatically when they pass through the photocell doors 5-m, 10-m, 30 meters ahead, and the 5-m, 10-m and 30-m sprint running time was measured. In the pretest and posttest measurements, the 5-m, 10-m and 30-m sprint tests were measured twice for each participant. Participants' best values were used for analysis. A 5-minute rest was given between the two speed tests.

\section{Statistical analysis}

All data were evaluated in the SPSS statistical package program (Version 17.0). The significance level was accepted as 0.05 . After the descriptive analysis of the participants, the normality test of the data was performed. Wilcoxon signed-rank test was used to test the significance of the difference between the participants' pre-test and post-test.

\section{RESULTS}

In this study, the effects of 6 weeks of NHE on speed and vertical jump performance were investigated. When the exercise group was compared with the control group, a significant increase was found in the $10 \mathrm{~m}$ and $30 \mathrm{~m}$ sprint performance in the exercise group. Unlike our hypothesis, there was no statistically significant increase in the $5 \mathrm{~m}$ speed and vertical jump performance of the exercise group.

Table 3. Experiment (EG) and control group (CG) 5-10-30 m sprint and vertical jump pre-test and post-test results

\begin{tabular}{|c|c|c|c|c|c|c|c|c|}
\hline & & \multicolumn{3}{|c|}{ Pre-test } & \multicolumn{3}{|c|}{ Post-test } & \multirow[b]{2}{*}{$\mathbf{p}$} \\
\hline & & $\mathbf{n}$ & xort & SS & xort & SS & $\mathbf{Z}$ & \\
\hline \multirow{2}{*}{ 5m Sprint } & EG & 10 & 1,02 & 0,05 & 1,00 & 0,07 & 1,37 & 0,169 \\
\hline & CG & 9 & 0,99 & 0,08 & 1,04 & 0,05 & 1,71 & 0,086 \\
\hline \multirow{2}{*}{ 10m Sprint } & EG & 10 & 1,78 & 0,07 & 1,75 & 0,11 & 2,49 & 0,012 \\
\hline & CG & 9 & 1,73 & 0,07 & 1,76 & 0,10 & 0,059 & 0,095 \\
\hline \multirow{2}{*}{ 30m sprint } & EG & 10 & 4,43 & 0,26 & 4,35 & 0,21 & 2,09 & 0,037 \\
\hline & CG & 9 & 4,34 & 0,23 & 4,39 & 0,21 & 1,66 & 0,097 \\
\hline \multirow{2}{*}{ CMJ } & EG & 10 & 35,63 & 4,72 & 36,35 & 3,89 & 1,07 & 0,258 \\
\hline & CG & 9 & 36,01 & 5,35 & 34,40 & 4,00 & 2,31 & 0,021 \\
\hline
\end{tabular}

$\mathrm{p}<0,05$ 
When the Wilcoxon signed-rank test analysis results are examined, it is seen that there is no statistically significant difference between the $5 \mathrm{~m}$ sprint test pre-test and post-test values of the participants in the experimental and control groups $(\mathrm{z}=1.37, \mathrm{p}>0.05)$. It is seen that there is a statistically significant difference between the $10 \mathrm{~m}$ and $30 \mathrm{~m}$ speed pretest values and the posttest values of the participants in the experimental group $\mathrm{p}<0.05)$. It is seen that there is no statistically significant difference between the vertical jump test pretest and posttest values of the participants in the experimental group $(\mathrm{z}=1.07, \mathrm{p}>0.05)$. When the vertical jump test pre-test and post-test values of the participants in the control group are examined, it is seen that there is a statistically significant difference $(\mathrm{z}=2.31, \mathrm{p}<0.05)$. Considering the mean and standard deviations, it is seen that this difference observed in the vertical jump value of the participants in the control group is in the negative direction, that is, in favor of the pre-test score.

\section{DISCUSSION}

In this study, the effects of 6 weeks of NHE on speed and vertical jump performance were investigated. In this study, we hypothesized that NHE would have positive effects on explosive properties. In line with our hypothesis, a significant increase was found in the $10 \mathrm{~m}$ and $30 \mathrm{~m}$ sprint performance in the exercise group when the control group and the exercise group were compared. Unlike our hypothesis, there was no statistically significant increase in the $5 \mathrm{~m}$ speed and vertical jump performance of the exercise group.

In line with our findings, Ishøi et al., (2018) in their study, showed that the 10-week Nordic Hamstring strength training protocol improved sprint acceleration performance $(10 \mathrm{mST})$, while repeated sprint performance and final performance sprint. In another study, strength training has been found to have a more positive effect for short sprint $\leq 10 \mathrm{~m}$ distances (Rumpf, Lockie, Cronin, \& Jalilvand, 2016). According to the results of a study, a four-week exercise program performed twice a week with NHE can be applied in professional football clubs and increase the eccentric knee flexor strength of male soccer players (de Oliveira et al., 2020). However, NHE is an effective training method for muscle hypertrophy (Seymore, Domire, DeVita, Rider, \& Kulas, 2017). The fact that the increase in muscle strength leading o an increase in sprint performance supports our hypothesis in this study. As a matter of fact, the improvement in $10 \mathrm{~m}$ Sprint and $20 \mathrm{~m}$ sprint performance in our study is likely to be related to strength adaptation in hamstring muscle due to NHE exercise. There was no statistically significant increase in $5 \mathrm{~m}$ sprint performance in our study this may probably due to the fact that the strength adaptation with NHE was not at a level that would provide an increase. However, sprints that have a great impact on the outcome of the match $(<10 \mathrm{~m})$ rather than long distance sprints in the match have gained more importance (Barnes, Archer, Hogg, Bush, \& Bradley, 2014; Schimpchen, Skorski, Nopp, \& Meyer, 2016). Various studies are carried out to prevent injury and increase performance at the same time. An interesting study by Freeman, B. W., et al (2019), found that 4 weeks of sprinting increased eccentric hamstring strength, but sprinting produced more muscle fatigue than NHE. However, Freeman, B. W., et al (2019), it can be used as an alternative method in balanced combination with NHE to increase eccentric hamstring strength and both prevent injury and improve athletic performance. 
Unlike our study, Clark, Bryant, Culgan, \& Hartley., (2005), found that in spide of a dramatic reduction in quadriceps peak torque and only minor changes in hamstring peak torque were determine in the open kinetic chain testing, a considerable increase in vertical jump height $(6.6 \%)$ was reported. This elicits that the Nordic hamstring exercise not only appears to have a beneficial effect on the length tension relationship of the hamstrings, but results in improve explosive power performance in untrained athletes (Clark et al., 2005). Similarly Nordic hamstring exercise effective to improve on explosive lower body performance in female rugby union players (Anastasi \& Hamzeh, 2011). The absence of a significant increase in vertical jump performance in our study may have been a single training application for the hamstring muscle. If we added a combined exercise for the quadriceps muscle, an increase in vertical jump would have been possible. Clark, et al., (2005), found that there may be various reasons for the increase in vertical jump after NHE, although the quadriceps peak torque, which has a direct effect on jump performance, decreased, but increased jump performance. Clark, et al., (2005) and in our study, this situation may probably be due to the jump technique. A change in hamstring position of peak torque at a wider knee angle may have an effect on the increase in vertical jump height. In other words, this increase in vertical jump may be due to the increased joint stability of the knee during the final take-off phase of the jump movement and may provide more efficient force transfer.

Limitations of this study, performing isokinetic strength measurement before and after 6 weeks of Nordic hamstring strength training could help us to see the improvement in muscle strength more accurately. In addition, evaluation of muscle strength by isokinetic dynamometer could provide further data regarding possible hamstring/quadriceps ratio and injury propensity.

\section{Acknowledgements}

This study was produced from a master thesis. We express our sincere thanks to all participants for following all our recommendations for testing during the study.

Conflicts of Interest: The authors declare that they have no conflict of interest.

Author Contributions: Both authors contributed equally to the preparation of this article and approved it for publication.

\section{Information on Ethics Committee Permission}

Committe: Kirıkkale University Faculty of Medicine Ethics Committee

Date: $21 / 06 / 2016$

Number: $17 / 013$ 
Gülü, M. \& Doğan, A.A. (2021). The effect of 6 week nordic hamstring exercise on sprint and jumping performance. Journal of Sport Sciences Researches, 6(2), 421-430.

\section{REFERENCES}

Al Attar, W. S. A., Soomro, N., Sinclair, P. J., Pappas, E. \& Sanders, R. H. (2017). Effect of injury prevention programs that include the Nordic hamstring exercise on hamstring injury rates in soccer players: A Systematic review and meta-analysis. Sports Medicine, 47(5), 907-916. doi: 10.1007/s40279-016-06382

Alonso, J.M., Edouard, P., Fischetto, G., Adams, B., Depiesse, F. \& Mountjoy, M. (2012). Determination of future prevention strategies in elite track and field: Analysis of Daegu 2011 IAAF Championships injuries and illnesses surveillance. British Journal of Sports Medicine, 46(7), 505-514. doi: 10.1136/bjsports-2012091008

Anastasi, S. M. \& Hamzeh, M. A. (2011). Does the eccentric Nordic Hamstring exercise have an effect on isokinetic muscle strength imbalance and dynamic jumping performance in female rugby union players? Isokinetics and Exercise Science, 19(4), 251-260. doi: 10.3233/IES-2011-0420

Aras, D., Gül, S., Akça, F., Gülü, M., Güler, Ö., Bıldırcın, C. C. \& Çetinkaya, G. (2020). Four-week of local electromyostimulaiton training on fingerboard increases the isokinetic wrist strength and endurance. Physical education of students, 24(3), 127-134. doi: 10.15561/20755279.2020.0301

Aydın, F., Sunay, H., Bal, E. \& Ayyıldız, E. (2019). The relation between self-efficacy and group cohesiveness perceptions of professional men and woman's football team (Ankara Province example). Universal Journal of Management, 33-38. doi: 10.13189/ujm.2020.080202

Barnes, C., Archer, D., Hogg, B., Bush, M. \& Bradley, P. (2014). The evolution of physical and technical performance parameters in the English Premier League. International journal of sports medicine, 35(13), 1095-1100. doi: 10.1055/s-0034-1375695

Bennell, K. L. \& Crossley, K. (1996). Musculoskeletal injuries in track and field: incidence, distribution and risk factors. Australian journal of science and medicine in sport, 28(3), 69-75.

Bourne, M. N., Opar, D. A., Williams, M. D. \& Shield, A. J. (2015). Eccentric knee flexor strength and risk of hamstring injuries in rugby union: a prospective study. The American journal of sports medicine, 43(11), 2663-2670. doi: 10.1177/0363546515599633

Brooks, J. H., Fuller, C., Kemp, S. \& Reddin, D. B. (2005). Epidemiology of injuries in English professional rugby union: part 1 match injuries. British Journal of Sports Medicine, 39(10), 757-766. doi: 10.1136/bjsm.2005.018135

Clark, R., Bryant, A., Culgan, J.P. \& Hartley, B. (2005). The effects of eccentric hamstring strength training on dynamic jumping performance and isokinetic strength parameters: a pilot study on the implications for the prevention of hamstring injuries. Physical Therapy in Sport, 6(2), 67-73. doi: 10.1016/J.PTSP.2005.02.003

Dawes, J. \& Lentz, D. (2012). Methods of Developing Power to Improve Acceleration for the Non-Track Athlete. Strength \& Conditioning Journal, 34(6), 44-51. doi: 10.1519/SSC.0b013e31827529e6

de Oliveira, N. T., Medeiros, T. M., Vianna, K. B., dos Santos Oliveira, G. \& de Araujo Ribeiro-Alvares, J. B., \& Baroni, B. M. (2020). A four-week training program with the Nordic hamstring exercise during preseason increases eccentric strength of male soccer players. International Journal of Sports Physical Therapy, 15(4), 571. doi: 10.26603/ijspt20200571

Dowling, J. J. \& Vamos, L. (1993). Identification of kinetic and temporal factors related to vertical jump performance. Journal of applied biomechanics, 9(2), 95-110. doi: 10.1123/jab.9.2.95

Ekstrand, J., Hägglund, M. \& Waldén, M. (2011). Epidemiology of muscle injuries in professional football (soccer). The American journal of sports medicine, 39(6), 1226-1232. doi: 10.1177/0363546510395879

Elliott, M.C., Zarins, B., Powell, J.W. \& Kenyon, C.D. (2021). Hamstring muscle strains in professional football players: A 10-year review. The American Journal of Sports Medicine, 39(4),843-850. doi:10.1177/0363546510394647. 
Gülü, M. \& Doğan, A.A. (2021). The effect of 6 week nordic hamstring exercise on sprint and jumping performance. Journal of Sport Sciences Researches, , 6(2), 421-430.

Enoka, R. M. (1988). Muscle strength and its development. Sports Medicine, 6(3), 146-168. doi: 10.2165/00007256-198806030-00003

Fang, Y., Siemionow, V., Sahgal, V., Xiong, F. \& Yue, G. H. (2001). Greater movement-related cortical potential during human eccentric versus concentric muscle contractions. Journal of Neurophysiology, 86(4), 17641772. doi: 10.1152/jn.2001.86.4.1764

Faul, F., Erdfelder, E., Lang, A.G. \& Buchner, A. (2007). G* Power 3: A flexible statistical power analysis program for the social, behavioral, and biomedical sciences. Behavior research methods, 39(2), 175191. doi: $10.3758 / \mathrm{bf03193146}$

Feeley, B. T., Kennelly, S., Barnes, R. P., Muller, M. S., Kelly, B. T., Rodeo, S. A. \& Warren, R. F. (2008). Epidemiology of National Football League training camp injuries from 1998 to 2007. The American journal of sports medicine, 36(8), 1597-1603. doi: 10.1177/0363546508316021

Franchi, M. V., Reeves, N. D. \& Narici, M. V. (2017). Skeletal muscle remodeling in response to eccentric vs. concentric loading: morphological, molecular, and metabolic adaptations. Frontiers in physiology, 8, 447. doi: 10.3389/fphys.2017.00447

Freeman, B. W., Young, W. B., Talpey, S. W., Smyth, A. M., Pane, C. L. \& Carlon, T. A. (2019). The effects of sprint training and the Nordic hamstring exercise on eccentric hamstring strength. The Journal of sports medicine and physical fitness, 59(7), 1119-1125. doi: 10.23736/S0022-4707.18.08703-0

Güçlüöver, A. \& Gülü, M. (2020). Developing a new muscle power prediction equation through vertical jump power output in adolescent women. Medicine, 99(25). doi: 10.1097/MD.0000000000020882

Hoppeler, H. (2014). Eccentric Exercise: Physiology and application in sport and rehabilitation (1st ed.). London: Routledge. doi:10.4324/9780203157862

Ishøi, L., Hölmich, P., Aagaard, P., Thorborg, K., Bandholm, T. \& Serner, A. (2018). Effects of the Nordic Hamstring exercise on sprint capacity in male football players: a randomized controlled trial. Journal of sports sciences, 36(14), 1663-1672. doi: 10.1080/02640414.2017.1409609

Konow, N. \& Roberts, T. J. (2015). The series elastic shock absorber: tendon elasticity modulates energy dissipation by muscle during burst deceleration. Proceedings of the Royal Society B: Biological Sciences, 282(1804), 1-8. doi: 10.1098/rspb.2014.2800

McFarland, I. T., Dawes, J. J., Elder, C. L., \& Lockie, R. G. (2016). Relationship of two vertical jumping tests to sprint and change of direction speed among male and female collegiate soccer players. Sports, 4(1), 1-7. doi: 10.3390/sports4010011

Mjølsnes, R., Arnason, A., Østhagen, T., Raastad, T. \& Bahr, R. (2004). A 10-week randomized trial comparing eccentric vs. concentric hamstring strength training in well-trained soccer players. Scandinavian journal of medicine \& science in sports, 14(5), 311-317. doi: 10.1046/j.1600-0838.2003.367.x

Moseley, L. (1996). The incidence of injury in surfboat rowers. Australian Journal of Science and Medicine in Sport, 28(4), 97-100.

Nimphius, S., McGuigan, M. R. \& Newton, R. U. (2010). Relationship between strength, power, speed, and change of direction performance of female softball players. The Journal of Strength \& Conditioning Research, 24(4), 885-895. doi: 10.1519/JSC.0b013e3181d4d41d

Opar, D., Williams, M., Timmins, R., Hickey, J., Duhig, S. \& Shield, A. (2015). Eccentric hamstring strength and hamstring injury risk in Australian footballers. Medicine and Science in Sports and Exercise, 47(4), 857865. doi:10.1249/MSS.0000000000000465

Orchard, J., James, T., Alcott, E., Carter, S. \& Farhart, P. (2002). Injuries in Australian cricket at first class level 1995/1996 to 2000/2001. British Journal of Sports Medicine, 36(4), 270-274. doi:10.1136/bjsm.36.4.270

Orchard, J., Wood, T., Seward, H. \& Broad, A. (1998). Comparison of injuries in elite senior and junior Australian football. Journal of science and medicine in sport, 1(2), 83-88. doi: 10.1016/s1440-2440(98)80016-9

Orchard, J. W., Seward, H. \& Orchard, J. J. (2013). Results of 2 decades of injury surveillance and public release 
Gülü, M. \& Doğan, A.A. (2021). The effect of 6 week nordic hamstring exercise on sprint and jumping performance. Journal of Sport Sciences Researches,, 6(2), 421-430.

of data in the Australian Football League. The American journal of sports medicine, 41(4), 734-741. doi: $10.1177 / 0363546513476270$

Rumpf, M. C., Lockie, R. G., Cronin, J. B. \& Jalilvand, F. (2016). Effect of different sprint training methods on sprint performance over various distances: A Brief review. Journal of Strength and Conditioning research, 30(6), 1767-1785. doi: 10.1519/JSC.0000000000001245

Schimpchen, J., Skorski, S., Nopp, S. \& Meyer, T. (2016). Are "classical" tests of repeated-sprint ability in football externally valid? A new approach to determine in-game sprinting behaviour in elite football players. Journal of sports sciences, 34(6), 519-526. doi: 10.1080/02640414.2015.1112023

Seymore, K. D., Domire, Z. J., DeVita, P., Rider, P. M. \& Kulas, A. S. (2017). The effect of Nordic hamstring strength training on muscle architecture, stiffness, and strength. European journal of applied physiology, 117(5), 943-953. doi:10.1007/s00421-017-3583-3

Shalfawi, S. A., Haugen, T., Jakobsen, T. A., Enoksen, E. \& Tønnessen, E. (2013). The effect of combined resisted agility and repeated sprint training vs. strength training on female elite soccer players. $J$ Strength Cond Res, 27(11), 2966-2972. doi: 10.1519/JSC.0b013e31828c2889

Stølen, T., Chamari, K., Castagna, C. \& Wisløff, U. (2005). Physiology of Soccer. Sports Medicine, 35(6), 501536. doi: 10.2165/00007256-200535060-00004

Timmins, R. G., Bourne, M. N., Shield, A. J., Williams, M. D., Lorenzen, C. \& Opar, D. A. (2016). Short biceps femoris fascicles and eccentric knee flexor weakness increase the risk of hamstring injury in elite football (soccer): a prospective cohort study. British Journal of Sports Medicine, 50(24), 1524-1535. doi:10.1136/bjsports-2015-095362

Turner, E., Munro, A. G. \& Comfort, P. (2013). Female Soccer: Part 1-A Needs Analysis. Strength \& Conditioning Journal, 35(1), 51-57. doi: 10.1519/SSC.0b013e318281f689

Except where otherwise noted, this paper is licensed under a Creative Commons Attribution 4.0 International license. 